\title{
PEMBERDAYAAN KELOMPOK TANI ORGANIK DI KABUPATEN BANTAENG
}

\author{
Muh. Nasir, H. Muhlis Madani, Anwar Parawangi \\ Universitas Muhammadiyah Makassar \\ e-mail: munawwirnuh1@gmail.com
}

\begin{abstract}
Abstrak
Penelitian ini bertujuan untuk menganalisis untuk mendeskripsikan implementasi pemberdayaan petani, kapasitas, kapasitas pemerintah dalam pemberdayaan yang digunakan pada petani organik dan untuk mendeskripsikan pengetahuan, pengembangan, dan pemberdayaan petani organik. Metode penelitian ini adalah pendekatan kualitatif dengan menganalisis semua data dan informasi yang bersumber dari data primer dan data sekunder dengan teknik wawancara dan observasi di Desa Biangloe Kecamatan Pajukukang Kabupaten Bantaeng Dinas Pertanian dan Ketahanan Pangan Kabupaten Bantaeng. Hasil penelitian menunjukkan bahwa program dukungan pemberdayaan kelompok tani/tani organik memiliki pengetahuan, keterampilan dalam usahatani padi organik, kemampuan yang telah diperoleh berdampak positif bagi petani, pada aspek penghematan pembiayaan pupuk organik, peningkatan beras produksi yang didukung dengan penerapan pola tanam, harga beras organik yang menjanjikan, sisi kesehatan lebih aman. Beberapa aspek kebijakan dalam pengembangan usahatani padi organik dirujuk di sini. Aspek pertama; Keberlanjutan baik standar nasional maupun bahasa operasi standar untuk prosedur organik tidak memiliki legalitas, artinya pemerintah masih dalam proses pedalaman untuk bantuan yang akan diberikan kepada petani organik, baik pembinaan dan pengawasan serta lembaga yang kompeten yang akan terlibat. Aspek kedua; Kelembagaan kelompok tani belum banyak berkontribusi dalam proses perencanaan kegiatan petani padi organik di pedesaan dan lebih terfokus pada pertanian anorganik, namun di sisi lain, dominasi RPJMDes sudah masuk dalam dokumen meskipun realisasinya dinilai masih belum memuaskan. semua pihak. Perencanaan program prima masih dapat ditingkatkan, koordinasi dan cakupannya dapat diperluas lintas jaringan SKPD lintas aktor/instansi, kebutuhan perencanaan program untuk mendukung pertanian organik di desa dan Kabupaten Bantaeng secara umum.
\end{abstract}

Kata Kunci: Program, pemberdayaan, kelompok tani, organik

\begin{abstract}
This study aims to analyze to describe the implementation of farmer empowerment, capacity, government capacity in empowerment used in organic farmers and to describe knowledge, development, and empowerment of organic farmers. This research method is a qualitative approach by analyzing all data and information sourced from primary and secondary data with interview and observation techniques in the Biangloe Village, Pajukukang District, Bantaeng Regency, the Agriculture Service \& Food Security Service of Bantaeng Regency. The results showed that the support program for empowerment of groups of farmers / organic farmers had knowledge, skills in organic rice farming, the abilities that had been obtained had a positive impact on farmers, on the aspect of saving on organic fertilizer financing, improved rice production which was supported by the adoption of planting patterns, prices the promising organic rice, the health side is safer. Several policy aspects in the development of organic rice farming are referred to here. The first aspect; The sustainability of either the national standard or the standard operating language for organic procedures does not have legality, meaning that the government is still in the inland process for assistance that will be provided to organic farmers, both guidance and supervision as well as competent institutions that will be involved. The second aspect; Farmer group institutions have not contributed much in the planning process of organic rice farmer activities in villages and are more focused on inorganic agriculture, but on the other hand, the RPJMDes dominance has been included in the document even though the realization is still considered unsatisfactory for all parties. Prime program planning can still be improved, its coordination and scope can be expanded across SKPD networks across actors / agencies, planning program needs to support organic farming in villages and in general Bantaeng Regency.
\end{abstract}

Kata Kunci: Programs, empowerment, farmer groups, organic 


\section{PENDAHULUAN}

Pemerintah, sebagai pemegang kekuasaan yang dimandatkan oleh warganya, membuat berbagai regulasi yang ditujukan kepada terciptanya kehidupan masyarakat yang sejahtera, kapasitas pemerintah dalam mendesain issu - issu program layanan kepada masyarakat petani, maupun kelompok,kepampuan pemerintah dalam mendesain yang didukung berbagai pendekatan dengan harapan dapat menjawab permasalahan dan kebutuhan.

Sebagaimana yang dikatakan Rubin (2003) mengidentifikasikan 10 (sepuluh) fungsi pemerintah dalam kaitannya denga pengembangan masyarakat, yaitu: a) Mendesain program pembangunan b) Pendanaan program dan pengalokasian sumber-sumber c)Penyediaan pelayanan langsung untuk warga masyarakat d) Menyelenggarakan pembangunan sarana dan prasarana e) Mengawasi kegiatan yang dipercayakan kepada pihak lain (swasta) f)Menciptakan hukum dan melakukan penguatan hokum g) Menyelenggarakan regulasi h) Melakukan negosiasi dan persuasi kepada pihak lain i) Melakukan adjudikasi dan mediasi j)Membuat perencanaan.

Dalam menjalankan fungsinya, pemerintah banyak atau dapat melakukan kerjasama dengan lembaga lain atau pun menuntut lembagalain untuk menyelenggarakan pemberdayaan, pengembangan masyarakat berbagai bidang, terutama peratania organik. Terkait aksi - aksi atau kegiatan yang dijalan oleh petani dikabupaten Bantaeng merupakan potensi daerah yang dapat lebih dikembangkan yang di dukung kebijakan pembangunan sebagaimana gambaran syarat komponennya adalah yaitu ketersediaan, distribusi, dan konsumsi. Ada yang menyebut ada 3 dimensi yaitu ketersediaan (availability), akses (access), dan pemanfaatan (utilization).

Menurut UU No.18 tahun 2012 tentang pangan, "Ketahanan Pangan" adalah kondisi terpenuhinya pangan bagi negara sampai dengan perseorangan, yang tercermin dari tersedianya pangan yang cukup, baik jumlah maupun mutunya, aman, beragam, bergizi, merata, dan terjangkau serta tidak bertentangan dengan agama, keyakinan, dan budaya masyarakat, untuk dapat hidup sehat, aktif, dan produktif secara berkelanjutan. Pengertian ketahanan pangan tersebut sejalan dengan tujuan sustainable develolment goals.Oleh karena itu, diperlukan usaha khusus untuk membuat masyarakat tani mau bertindak memanfaatkan kesempatan perbaikan kehidupannya. Kemampuan masyarakat bertani untuk berpartisipasi dalam pembangunan harus didahului oleh suatu proses belajar untuk memperoleh dan memahami informasi, kemudian memprosesnya menjadi pengetahuan tentang adanya kesempatan bagi dirinya, melatih dirinya agar mampu berbuat, dan termotivasi agar benar-benar bertindak. Bertitik tolak yang diatas tentang kebijakan ketahanan pangan, sangat diharapkan kebijakan yang dapat meningkatkan harkat martabak masyarakat sebuah bangsa dan kebijakan tidak terjebak pada kepentingan global. Disisi lain Kapasasitas pemerintah memang diharapak dalam menerjemahkan kondisi apa yang dapat mendukung pembagunan berkelanjutan.

Pembangunan di sektor pertanian mesti mengedepankan pendekatan agroekologis. Artinya, pembangunan pertanian bukan hanya sekedar mengejar peningkatan produktifitas komoditi namun pemulihan ekosistem juga mesti diutamakan. Pemerintah harus mengurangi dan bila perlu menghentikan impor pestisida kimiawi, membangun bank benih lokal di desa-desa serta produk olahan pertanian alami lainnya sehingga tercipta kemandirian benih dan produk alami lainnya di tingkat desa, serta pemerintah juga harus membangun infrastruktur pertanian yang meningkatkan daya dukung lingkungan.

Dukungan kapasitas untuk menggunaan kembali polah kebiasaan bertani sesuai dengan kearifan lokal akan dapat berkentribusi secara positif walaupun proses tidaklah mudah mengembalikan, yaitu penggunaan pupuk organik beserta pestisida organik (dalam pertanian organik) masih belum diminati. Hal ini disebabkan hasil pertanian an-organik dalam jangka pendek lebih menguntungkan dibanding hasil pertanian organik. Perlindungan dan kesadaran mereka terhadap usaha tani organik memang belum mendapatkan perlakuan yang begitu mengembirakan, sehingga sangat berpengaruh terhadap sikap dan perilaku serta partisipasi mereka terhadap pengembangan usaha tani organik. Peraturan Mentri Pertanian No. 
64/Permentan/OT.140/5/2013, tentang sistem pertanian organik, dan Peraturan Daerah Kabupaten Bantaeng No. 09 Tahun 2013 tentang Pemberdayaan Petani dan Nelayan.

Dari uraian diatas sebelumnya, bahwa pembangunan yang diaharapkan magaimana terbangun pembangunan berkeadilan sosial masyarakat dan utamanya petani kurang mampu, usaha pertanian organik dapat menjadi komponen kebijakan dan proses pembangunan"tranformasi sosial", karena berhubungan atau punya hubungan sosial politik untuk menjadi relasi yang adil, pada konteks usaha pembangunan pertanian sehat dan produktif.

Melihat kecenderungan yang nampak di Desa Biangloe, serta Desa lain dimana kegiatan bertani alami/organik yang dilakukan oleh petani yang tergabung dalam Lembaga Serikat Tani Alami Butta Toa, aktif memperkenalkan kegiatan sistem bertani alami/organik yang baik maka dalam pembahasan penelitian ini penulis mengangkat judul: "Pemberdayaan Kelompok Tani Organik Di Kabupaten Banataeng" (Study Penelitian Di Desa Biangloe, Kecamatan Pajukukang)

\section{TINJAUAN PUSTAKA}

Dalam komponen kebijakan publik, Peningkatan kualitas derajat hidup masyarakat, serta sektor petani/sub sektor petani organik menjadi tujuan kebijakan negara dalam perlindungan, melayani masyarakat petani baik individu, kelompok dengan pemberian pelayanan yang menunjang aktivitas usaha pertananian organik, proses pemberdayaan membutuhkan pemetaan kodisi sosial masyarakat untuk sebagai langka dalam menjawab permasalahan dan kebutuhan dalam konteks pemberdayaan, pertanian organik dimana pemahaman masyarakat terhadap suatu program merupakan bentuk pandangan dan berkentribusi yang dapat membentuk sebuah penilaian dan dapat mengarahkan pada sebuah tindakan untuk kebaikan dirinya, maupun lingkungan.

Adapun tingkat penilaian petani merupakan ukuran baik dan tidak baiknya atau positif dan negatifnya suatu program yang dapat membentuk sikap penerimaan atau penolakan terhadap suatu program, seperti yang diungkap oleh Baron dan Byrne (2003) yang dikutip oleh Lokita (2011) ketika individu memiliki sikap yang kuat terhadap isu-isu tertentu, maka mereka seringkalibertingkah laku konsisten dengan pandangan tersebut. Penilaian yang positif terhadap suatu program pemberdayaan akan mendorong responden untuk terlibat dalam rangkaian kegiatan program pertanian dan usaha petani organik. Dapat diambil kesimpulan mengenai makna tersebut bahwa pengetahuan dan kesadaran tentang suatu isu tertentu merupakan suatu bentuk penilaian yang menentukan sikap seseorang negatif atau positif terhadap issu ataupun program tertentu dan hal ini turut mempengaruhi perilaku seseorang untuk menolak atau menerima isu atau program tersebut. Memang dapat dibenarkan terkait ungkapan diatas, tentunya pemberdayaan masyarakat petani organik terkait langka - langka apa dan pemetaan lingkungan sosial masyarakat, peran pemerintah dan lembaga lain/swasta juga ikut didalamnya dalam melakukan proses penyadaran lewat melalui berbagai program kebijakan dengan pendekatan, seminar, tudang sipulung, lokakarya, serta kegiatan lain. Dari pendekatan kebijakan program peberdayaan masyarakat, sub pendekatan yang selalu dihadirkan "partisipasi" merupakan dapat memungkinkan terbangun keinginan yang kuat dalam mengawal dan melakukan kegiatan pertanian organik serta melibatakan petani lain untuk mengetahui atau petani kofensional untuk dapat melakukan hal yang sama, terkait dukungan yang diharapkan dari pemangku kepentingan dalam hal ini pemerintah juga sangat diharapak kehadirannya dalam memberikan dukungan berkelanjutan melalui kebijakan,baik kebijakan dalam mengawal penyadaran dan peningkatan pengetahuan petani dalam pertanian organik dan fasilitasi dukungan lainnya terkait sarana prasarana yang lebih diperluas untuk dapat meningkatakan akses kualitas hidup.

Dan terkait pengembangan pemberdayaan pertanaian organik akan dapat terus berjalan dan mendapatkan tempat dimasyarakat petani apabilah program pertanian organik dikawal para pelaku aktifis sosial yang bergerak dipertanian alami dan mendapatkan kepercayaan dari Pemerintah baik ditingkat desa sampai Kabupaten. Pemberdayaan menunjuk pada kemampuan orang, khususnya 
kelompok rentan dan lemah sehingga mereka memiliki kekuatan atau kemampuan dalam:

a. Memenuhi kebutuhan dasarnya sehingga mereka memiliki kebebasan.

b. Menjangkau sumber-sumber produktif yang memungkinkan mereka dapat meningkatkan pendapatannya dan memperoleh barang-barang dan jasa-jasa yang mereka perlukan.

c. Berpartisipasi dalam proses pembangunan dan keputusan-keputusan yang mempengaruhi mereka (Suharto, 2005).

Menurut Ife (dalam Suharto, 2005), pemberdayaan memuat dua pengertian kunci, yakni kekuasaan dan kelompok lemah. Kekuasaan di sini diartikan bukan hanya menyangkut kekuasaan politik dalam arti sempit, melainkan kekuasaan atau penguasaan klien (sasaran) atas: a) Pilihan-pilihan personal dan kesempatan-kesempatan hidup: kemampuan dalam membuat keputusankeputusan mengenai gaya hidup, tempat tinggal, dan pekerjaan. b) Pendefinisian kebutuhan sebagai kemampuan menentukan kebutuhan selaras dengan aspirasi dan keinginannya. c) Ide atau gagasan diartikan sebagai kemampuan mengekspresikan dan menyumbangkan gagasan dalam suatu forum atau diskusi secara bebas dan tanpa tekanan. d) Lembaga lembaga kemampuan menjangkau, menggunakandan mempengaruhi pranatapranata sosial masyarakat, seperti lembaga kesejahteraan sosial, pendidikan, dan kesehatan. e) Sumber-sumber, maksudnya adalah kemampuan memobilisasi sumbersumber formal, informal, dan kemasyarakatan. f) Aktivitas ekonomi merupakan kemampuan memanfaatkan dan mengelola mekanisme produksi, distribusi, dan pertukaran barang serta jasa. g) Reproduksi yaitu kemampuan dalam kaitannya dengan proses kelahiran, perawatan anak, pendidikan dan sosialisasi.

Pemberdayaan petani, kelompok tani, merupakan hal penting dalam setiap rumusan kebijakan dan menjadikan komponen program kebijakan pelayanan /sub sektor usaha pertanian organik untuk dilakukan di tengah permasalahan pertanian serta ketidakberdayaan petani dalam mengembangkan usahanya. Dengan menghadirkan Program kebijakan Pemerdayaan kelompok tani dengan penggunaan pupuk organik diharapkan mampu meningkatkan potensi yang dimiliki oleh petani, terutama dalam mengatasi permasalahan seperti rendahnya daya tawar dan terbatasnya akses permodalandari pemerintah serta tingkat pendidikan petani yang masih rendah, kemampuan membuat pilihan bagi petani. Proses pemberdayaan pertani merupakan siklus atau proses yang melibatkan peranan petani untuk berkerja sama dalam kelompok formal maupun nonformal untuk mengkaji masalah, merencanakan, melaksanakan, dan melakukan evaluasi pada program yang direncanakan bersama petani untuk konsisten mengembangkan sistem pertanian organik yang berkelanjutan.

Beberapa upaya dari kebijakan pemerintah dalam pemberdayaan petani dalam sistem pertanian organik melalui tiga arah yaitu:

Menciptakan suasana atau iklim yang memungkinkan potensi sumber daya alam dan manusia untuk dapat berkembang (enabling). Hal ini dengan menyadarkan setiap individu maupun masyarakat bahwa petani memiliki potensi karena tidak ada masyarakat yang tidak memiliki daya. Sehingga ketika melaksanakan pemerdayaan diupayakan mendorong dan membangkitkan motivasi masyarakat akan pentingnya mengembangkan potensi-potensi yang telah ada dan dimiliki oleh petani.

Memperkuat potensi atau daya yang dimiliki oleh petani (empowering). Dalam pemberdayaan diupayakan melalui kegiatan /aksi nyata seperti pendidikan, pelatihan, pemberian akses modal, dan infrastruktur untuk menunjang keberlanjutan sistem pertanian organik. Pemberdayaan bukan hanya meliputi penguatan individu petani melainkan menanamkan nilai-nilai sistem pertanian organik yang ramah lingkungan bermodalkan kerja keras dan tangung jawab.

Melindungi hak petani organik (protection) artinya dalam pemberdayaan petani dalam upaya mencegah persaingan yang tidak seimbang maupun praktek eksploitasi oleh kaum /pihak yang kuat terhadap kaum /pihak yang lemah.

\section{METODE}

Penelitian yang digunakan dalam penelitian ini adalah pendekatan kualitatif, 
Pendekatan kulaitatif dipilih karena dapat digunakan untuk mengungkap dan memahami sesuatu di balik fenomena yang belum diketahui. Selain itu, metode kualitatif dapat memberi rincian yang kompleks tentang fenomena yang sulit diungkapkan oleh metode kuantitatif. (Sugiyono, 2010).

Teknik analisis data dalam penelitian deskriptif kualitatif dengan mendeskripsikan kualitas suatu gejala yang menggunakan ukuran perasaan sebagai dasar penilaian (Slamet, 2006). Selain mendeskripsikan juga menceritakan hubungan atau keterkaitan antar gejala, serta seberapa jauh terdapat kesepakatan atas hasil-hasil yang disampaikan. seluruh data dan informasi yang bersumber dari data primer dan sekunder dengan teknik wawancara dan Penelitian ini di lakukan di Desa Biangloe, Kecamatan Pajukukang, Kabupaten Bantaeng

\section{HASIL DAN PEMBAHASAN}

\section{Pemberdayaan kelompok Tani Organik di Kabuapten Bantaeng.}

Peraturan Daerah Kabupaten Bantaeng No. 09 Tahun 2013 tentang Pemberdayaan Petani dan Nelayan, dalam pengertian pemberdayaan petani dan nelayan bertujuan "meningkatkan kemandirian petani dan nelayan dalam rangka mewujudkan taraf kesejahteraan, kualitas, dan kelangsungan hidup yang lebih baik.

\section{a. Penyadaran petani}

Dalam mendukung program pertanian organik yang telah direncanakan pihak - pihak terakit seperti pemerintah desa Biangloe, Dinas Pertanian, dinas Ketahanan Pangan. Program kegiatan yang dilalui fokus pada dukungan kegiatan penyadaran, peningkatan pengetahuan, keterampilan bagi petani baik itu petani anorganik dan petani organik. Untuk akses dukungan program kegiatan sarana pupuk organik untuk pihak - pihak tekait dalam hal ini pemerintah secara umum belum dapat melayani pada aspek penyediaan pupuk organik bagi petani. Orentasi pemerintah bagaimana petani dapat beradaptasi dengan sumber-sumber lokal, tentu dengan proses pembelajaran dilakukan melaui peningkatan pengetahuan dan keterampilan bagi petani serta bagiamana memanfaatkan sumber - sumber kekayaan lingkungan yang tersedia limbah ternak, alam lain seperti pemanfaatan hijauan untuk diolah menjadi pupuk cair orgnik, maupun racun hama yang ramah lingkungan.

Dengan polah yang dilalui strategi penyuluhan, pelatihan, pecontohan oleh pendamping teknis bagi petani. Petani Usahatani padi organik telah memiliki kemampuan dibidang pengetahuan teknis untuk pengelolaan limbah ternak menjadi sesuatu berharga untuk mendukung usahausaha dalam pengelolaan pertanian yang ramah lingkungan. Penyelenggaraan kegiatan "Sosialisasi" pertanian organik kepada petani diinisiasi pemerintah desa bersama Lembaga Serikat Petani Alami Butta Toa selaku mitra pemerintah desa serta OPD Dinas Pertania dan Dinas Ketahanan Pangan Kabupaten Bantaeng merupakan implementasikegiatan multipihak, kebijakan pelayanan publik pada sektor pelayanan informasi bagi petani utamanya pertanian organik, kegiatan dibanyak tempat bertema pertanian organik. Kegiatan terselenggara atas dukungan dan kemampuan pemerintah kabupaten, pemerintah desa memberikan ruang bagi bagi petani membuat perencanaan, penganggaran yang bersumber APBDes untuk dipergunakan kerja-kerja pasilitasi kegiatan pertanian organik.

\section{b. Pengkapasitasa}

Manajemen yang dilakukan petani penerapan polah bertahap telah dialakukan dengan pola tanam tumpan sari satu petak diperuntuhkan padi, petak lainya ditanami sayuran baik kangkun, tomat, montimun, terong. Polah ini dilakukan petani padi organik untuk mengngantisifasi jarak panen padi lebih tiga bulan sementara tanaman sayuran sifat peretumbuhan lebih cepat dan hasil penjualan dapat menutupi ekonomi keluarga dengan polah ini tetap digunakan pemupukan kompos organik dan dibantu pupuk cair organik plus hama organik. Pada aspek manajemen polah tanam yang dilakukan parapetani padi organik telah dijadikan pilihan dalam menjawab jarak masa tanam padi dengan masa panen, melalui manajemen tumpan sari itulah yang digunakan masa transisi untuk digunakan kebutuhan ekonomi keluarga.Tentu proses ini bukan sesuatu sangat mudah dilalui dari petani an organik menjadi petani organik, namun pada kendisi tertentu akan mencari polah kebiasan 
ketika akses ketersediaan sumber bahan baku (kompos/limbah) ternak habis tidak menutup kemungkinan akan bertani an organik dengan polah yang berbeda, dan itu juga yang terjadi seperti kasus seorang petani organik "dg sangkala" mengatakan pertanian organik memang cukup menjanjikan kalau petani sekaligus penggarap. Namun saya kembali bertani an organik karena pemilik lahan tidak mendukung program pertanian organik.

\section{c. Peningkatan Hasil Panen \&Pendapatan Meningkat \\ Dalam kaitan Program Pemberdayaan} Pemerintah melalui proses pendampingan penyadaran dari rentetan serta fase yang dijalani bagi petani organik, sesuai dengan penyuluhan dan percontohan serta dilakukan, melaksanakan program dan meraskan asas manfaat bagi dirinya. Model yang digunakan adalah penyuluhan, percontohan dan pelatihan. Penyuluhan yang diberikan adalah penyuluhan usahatani yang dilakukan secara bertahap. Percontohan dilaksanakan langsung di sawah dengan sistem demonstrasi dan pelatihan. Untuk pelatihan dilakukan melalui ketrampilan membuat pupuk kompos dan ketrampilan pengolahan tanah dengan pupuk kandang (organik). Ketiga komponen pemberdayaan petani oleh pendamping jika dikaitkan dengan pandangan hidup bagi kita sebagi petani merupakan modal ini dikembangkan kepada petani lain, denganpendapatan usahatani padi organik setelah pemberdayaan selama masa Program sebagaimana telah disebutkan sebelumnya, bagi kita sebagai petani yang telah bergeluk dipertanian organik dan itulah yang dikembangkan terus-menerus, berdampak peningkatan hasil dan pendapatan, dan menjadi perencanaan yang kami kembangkan selama ini dan dikaitkan dengan perhitungan berikut : (1)Hasil panen per hektar/musim tanam 3,75 ton gabah kering, yang kemudian diolah menjadi beras sebanyak $3.213 \mathrm{~kg}$ dan menir sebanyak $357 \quad \mathrm{~kg},(2) \quad$ Penerimaan (pendapatan kotor) petani dari penjualan beras dan menir/hektar/musim tanam sebesar Rp. 48.195.000,- (3) Total biaya usahatani/hektar/musim tanam sebesar Rp. 4.985.500,- (4) Pendapatan petani Rp. 43.209.500,--

\section{KESIMPULAN DAN SARAN}

Program Pemerintah dalam Pendampingan Pemberdayaan Kelompok tani atau petani dikabupaten Bantaeng telah berdampak positif yang dirasakan bagi petani dalam peningkatan pengetahuan dan keterampilan untuk mendukung usaha pertanian, dalam mengakses kegiatan-kegiatan yang dilakukan baik yang dilaksanakan pemerintah desa dan dinas ketahanan pangan, dinas pertanian, dan pendamping teknis Serikat Petani Alami Butta Toa, Penyuluh Petani Lapang, kelompok tani biangloe melaui jejaring kegiatan yang difasilitasi ditempat lain tidak lain menjadi bagian dari kentribusi yang tidak terpisahkan untuk mendukung pengetahuan, keterampilan bagi petani.

Bagi pemerintah perlu ditingkatkan pendampingan kembali dengan perencanaan yang lebih fokus pada berbagai aspek bidang sektor untuk mendukung keberlanjutan usahatani organik yang ada dikabupateng bantaeng. Mengaktifkan peran BUMDes Desa Biangloe dengan penyertaan modal melalui BUMDes Biangloe untuk mendung pemasaran usaha beras organik bagi petani

\section{REFERENSI}

Abdillah Hanafi, 1981, Memasyarakatkan Ide-Ide Baru, disarikan dari karyaEverett M.Rogers dan F. Floyd Shoemaker. Surabaya: penerbit UsahaNasional,.

Agung, Igusti Ngurah, 2004, Manajemen Penulisan Skripsi, Tesis dan Disertasi, Jakarta: PT. Raja Grafindo Persada.Andoko, Agus, 2005, Budidaya Padi Secara Organik, Jakarta: Penebar Swadaya.

Anonimouse, 1996, Penyuluhan Pembangunan Kehutanan, Jakarta: Departemen Kehutanan. 2000, Pedoman Penyelenggaraan Penyuluhan Agrobisnis dalamOtonomi Daerah, P4BP3MP, Jakarta: Departemen Pertanian.

Azwar, Saifuddin, 2004, Reliabilitas dan Validitas, Yogyakarta: Pustaka Pelajar. 2005, Sikap Manusia Teori dan Pengukurannya, Yogyakarta: Pustaka Pelajar. 
Ahmar, Mappamiring, Anwar Parawangi (2016), Peranan Pemerintah dalam Pemberdayaan Petani di Desa Parunpanai Kecamatan Wasuponda Kabupaten Luwu Timur. Jurnal Kolaborasi.

Budi Winarno, 2016. Kebijakan Publik Era Globalisasi "teori, proses, \& studi kasus kompratif". PT. BukuSeru, Cet.I. Yogyakarta

Bintoro (2014-2015) Peranan Pemerintah Daerah dalam Mendorong Pembangunan Pertanian Menuju Kedaulatan Pangan (studi kasus di dinas pertanian kabupaten sragen) Jurnal Skripsi.

Craig, G. Dan M. Mayo (ed.). 1995. Community Empowerment: A Reader in Participation and Development. London: Zed Books.

David Korten, 1984. Pembagunan Berpusat Pada Mayarakat " People Contered Development"

Dimyati, A. 2002.Dukungan Penelitian dalam PengembanganHortikultura Organik.

Edi Suharto. 2005. Membangun Masyarakat Membangun Rakyat. Bandung: PT.Refika AditamaGerungan, WA, 1981. Psikologi Sosial, PT. Eresco, Bandung.

Wilda Tul Wuluf (2019), yang meneliti tentang Strategi Pemberdayaan Petani Padi Organik Dalam Meningkatkan Kesejahteraan Ekonomi Desa Lombok Kulon Kecamatan Wonosari Kabupaten Windowoso Jawa Timur.

I Gede Sidemen, Hartayo, Gunakan Budikahono,(2012), Penelitian ini dilakukan terhadap komunitas petani organik di Kecamatan Metro Kibang, Lampung Timur yang menjadi anggota Ikatan Pelopor Pertanian Organik Lampung (IPPOL). Jurnal

Ginandjar Kartasasmita.1995. Pemberdayaan Masyarakat: SebuahTinjauan Administrasi. Jakarta: Buletin Alumni SESPA Edisi IV.

Gunawan, Sumodiningrat. 1995.

Pemberdayaan Masyarakat Jakarta: PT. Gramedia Pustaka Utama.

Haryono, 2004. Hubungan Sikap Masyarakat Dan Karakteristik MahasiswaPeserta Kuliah Kerja Pemberdayaan
Masyarakat (KKPM) Dengan Tingkat Partisipasi Masyarakat Dalam Pembangunan Desa Di Kecamatan Tanon Kabupaten Sragen Tahun 2002 - 2003. Tesis Progdillmu Komunikasi, Fakultas Pascasarjana, Universitas Sebelas Maret Surakarta.

Hikmat, Harry, 2004, Strategi Pemberdayaan Masyarakat, Bandung: Humaniosa Utama Press.

Ife, Jim. 1995. Community Development. Australia: Longman Australia Pty. Ltd.

Joko Pramono, 2004. Kajian Penggunaan Bahan Organik Pada Padi Sawah, Agrosains Vol. 6, No 1, Januari - Juli 2004. Fakultas Pertanian UNS.

Karwan.A.Salikin, 2003, Sistem pertanian Berkelanjutan. Yogyakarta: penerbit Kanisius.

Kirk, J. \& Miller ML. 1986. Reliability and Validity In Qualitative Research. Beverly Hills, CA: Sage Publications, Inc.

Mardikanto, T, 2001, Prosedur Penelitian Penyuluhan Pembangunan untukPemberdayaan Masyarakat, Surakarta: Prima Theresia Pressindo.1988, Komunikasi Pembangunan, Surakarta: UNS Press.1993, Penyuluhan Pembangunan Kehutanan, Jakarta: Departemen Kehutanan.

MacArdle, J. 1989. "Community Development Tools of Trade."Community Quartely Journal Vol. 16.

Mar'at, 1984. Sikap Perubahan Serta Pengukurannya, Psikologi UNPAD. Bandung: Ghalia Indonesia.

Mikkelsen, Britha, 2003, Metode Penelitian Partisipatosis Dan UpayaUpayaPemberdayaan (Sebuah Buku Pegangan Bagi Para Praktisi Lapangan), Terjemahan Oleh: Matheos Nalle, Jakarta: Yayasan Obor.

Manyour Fakih, 2008. RuntuhnyaTeori Pembanguanan \& Globalisasi "Insist Press-Pustaka Pelajar".

Mansur Fakih, 2002, "Sebuah Buku Jalain Lain-Manifesto Intelektual Organik". Insist Press-Pustaka Pelajar 
Moleong, Lexy J. 2006. Metodologi Penelitian Kualitatif. Bandung: Remaja Rosdakarya.

Mosher, A.T., 1966. Menggerakkan dan Membangun Pertanian. Jakarta: CV. Yasaguna.

Nurgiantoro, B, Gunawan dan Marzuki, 2004, Statistik Terapan Untuk PenelitianIlmu-Ilmu Sosial, Yogyakarta: UGM Press

Poerwadarminta, W.J.S., 1987, Kamus Umum Bahasa Indonesia, Jakarta: PN. Balai Pustaka.

Pranarka Vidhyandika M. 1996. "Pemberdayaan" dalam Onny S.P. dan A.M.W. Pranarka (ed.). Jakarta: CSIS. Pratiwi I.K.S., 2004. Analisis Penggunaan Faktor Produksi Pada Usahatani PadiSemi Organik di Kabupaten Sragen).

Rappaport, J. 1987. "Terms of Empowerment: Toward a Theory for CommunityPsychology." American Journal of Community Psychology, Vol. 15. No.2.

Reiinties, Coen, Haverkort, Bertus, dan Waters Baver, Ann, 1992, PertanianMasa Depan, Yogyakarta: Kanisius.

Retno Lantarsih, Irene Kartika Eka Wijaya, Sipri Paramita, 2003. StudiKomparatif Pengaruh Karakteristik Beras Organik dan An-Organik Terhadap Permintaan Konsumen Rumah Tangga di Perkotaan Daerah Istimewa Yogyakarta, Agrosains Vol. 5, No 2, Januari 2004, FakultasPertanian UNS.

Siahaan, S.M.DR.Pdt., 1998, Komunikasi Pemahaman dan Penerapannya, Jakarta: Penerbit PT BPK, Gunung Mulia.

Setiana, Lucie, M.P., IR, 2005, Teknik Penyuluhan dan PemberdayaanMasyarakat, Bogor: Ghalia Indonesia.

Slamet, Margono, 2003, Membentuk Pola Perilaku Manusia Pembangunan, Bogor: IPB Press.

Slamet Y, 1993, Analisis Kuantitatif Untuk Data Sosial, Solo: Dabara Publisher.

Slamet Y, 2006, Metode Penelitian Sosial, Solo : Sebelas Maret Univerity Press1994, Pembangunan Masyarakat Berwawasan Partisipasi, Surakarta: UNS Press.
Soerjono Soekanto, 1990, Sosiologi Ilmu Pengantar, Jakarta: Rajawali Pers.

Soesarsono Wijandi, 1988, Pengantar Kewiraswastaan, Bandung; Penerbit Sinar Baru.

Soetrisno, Loekman, 2002, Paradigma Baru Pembangunan Pertanian SebuahTinjauan Sosiologis, Yogyakarta: Kanisius

Sugiyono, 2005, Memahami Penelitian Kualitatif, Bandung: Alfa Beta

Suhardiyono, 1989, Penyuluhan Petunjuk Bagi Penyuluh Pertanian, Erlangga.

Suhartini, Rr.,dkk., 2005, Model-Model Pemberdayaan Masyarakat. Yogyakarta: Penerbit Pustaka Pesantren.

Suharsimi A \& Cepi Safruddin AJ, 2004, Evaluasi Program Pendidikan, Jakarta: PT. Bumi Aksara.

Suharto, Edi, 2005, Membangun Masyarakat Memberdayakan Rakyat, Bandung: PT Rifika Aditama.

Sukmana Soleh, 1990, Petunjuk Teknis Usahatani Konservasi Daerah AliranSungai, Salatiga: Badan Penelitian dan Pengembangan PertanianDepartemen Pertanian.

Solita Sarwono, 1993, Sosiologi Kesehatan,Yogyakarta: Gajah Mada University Pers.

Sulistiya Ekawati, 2005, Aspek Sosial Budaya Proses Terbangunnya HutanRakyat Swadaya. Surakarta: PPs. Universitas Sebelas Maret.

Suprapti Supardi, Djiwandi, Priyo Prasetyo, 1991, Pengantar Ekonomi Pertanian: Departemen Pendidikan Dan Kebudayaan Republik Indonesia, UNS. Surakarta.

Suratiyah Ken, 2006, Ilmu Usahatani. Jakarta: Penebar Swadaya

Suriawiria, Nuus, 2002, Pupuk

$$
\text { Organik Kompos Dari }
$$
Sampah, Bandung: Humaniora Utama Press.

Suryana, A.1997. "Pertanian 2020, Tidak Dapat Dengan Pendekatan Biasa Lagi."dalam Kompas, 7 Maret.

Susilo, Agung, 2005, Pertanian Dalam Globalisasi, Yogyakarta: Kanisius

Sutanto, Rachman, 2002, Pertanian Organik, Yogyakarta: Kanisius 
Sutopo, H.B, 2002, Metodologi Penelitian Kualitatif, Surakarta: UNS Press.

Tayibnapis, F.Y, 2000, Evaluasi Program, Jakarta: PT. Rineka Cipta

Usman, Sunyoto, 2003, Pembangunan dan PemberdayaanMasyarakat, Yogyakarta: Pustaka Pelajar.

Van Den Ban. A.W., dan Hawkins. H.S, Penyuluhan Pertanian, Yogyakarta: Kanisius.

Young, T. And Burton, M.P. 1992. Agricultural Sustainability: Definition andImplication for Agricultural and Trade Policy. FAO-UN,Rome,I

Prosiding Seminar Nasional dan Pameran Pertanian Organik, Jakarta. Hlm 109 128.FAO. 1999. Organik agriculture. Committee on Agriculture. http://www.fao. org/unfao/bodies/coag/coag15/x0075e. htm. 4 juni 2007.

Husnain, H. Syahbudin, dan D. Setyorini, 2005. Mungkinkah Pertanian Organik di Indonesia? Peluang dan Tantangan. Inovasi 4 (17): 8-13.

IFOAM. 2005. Principles of Organic Agriculture. IFOAM General Assembly. Adelaide.

Biocert.or.id/infoguide-info.php?id=76-23k 25 September 2007

Undang-Udang Nomor 32 Tahun 2004 tentang arah Kebijakan Pemerintahan Dearah yang telah dipertegas dalam GBHN

Undang - Undang Replik Indonesia Nomor 32 2004 atas pergantian Undan-undang Nomor 22 Tahun 1999 Tentan Pemerintahan Daerah

Undang - undang Republik Indonesia Nomor 6 Tahun 2014 Tentang Pemerintahan Desa

Undang - undang Nomor 18 Tahun 2012 Tentang "ketahanan pangan"

Undang - undang Nomor 16 Tahun 2006 Tentang Sistem "penyuluhan pertanian, perkanan, dan kehutanan"

Permentan Nomor 47 Tahun 2016 Tentang Pedoman Penyusunan Program Penyuluhan

Permendagri tentang Susunan Dan Struktur Kelembagaan Pemerintahan Desa

Permendagri Tentang Susunan \& Struktur Organisasi Kelembagaan Desa
Peraturan Mentri Pertanian RI, Nomor 01 Tahun 2019 Tentang Pendaftaran Pupuk Organik, Pupuk Hayati, dan Pembenah Tanah

Peraturan Daerah Kabupaten Bantaeng Nomor 9 Tahun 2013 Tentang Pemberdayaan Petani Dan Nelayan

"Program" Dokumen WISMP II Kabupaten Bantaeng Tahun 2014-2017

Program Pendampingan (TPM) WISMP II di 11 Derah Irigasi Tahun 2014-2017 Kabupaten Bantaeng

H.Nurun, Kades Biangloe, 2019 Oktober, wawacara Dukungan pemerintah desa dalam peningkatan kapasitas petani, masyarakat dalam perubahan mindset dari polah kebiasan lama.

Hartawan, Wawancara Oktober 2019,Plt Dinas Pertanian Kabupateng Bantaeng "kadis pertanian" Budi Taufik

ingrad Ir. Andi Nisnawati, Wawacara November 2019, Kabid Program Dinas Ketahanan Pangan Kabupaten Bantaeng

Mubaraq Budi, Wawancara Oktober 2019, Kabid Program Penyuluhan Petani Lapangan Dinas Pertanian Kabupateng Bantaeng

M. Awalauddin, Wawancara Oktober 2019, Perani, Aktor SPA Butta Toa

Muh. Iksan, Wawancara September 2019, Petani, Ketua SPA Butta Toa

Bondan, wawancara November 2019, PPL Desa Biangloe

M. Sakir, wawancara Oktober 2019, Pengurus Kelompo Tani, Petani Desa Biangloe

Fajar Muhammad, wawancara November 2019 Petani

Musa Dg, wawancara November 2019

Muh. Wahid, wawancara Oktober 2019

Dokumen RPJMDes Biangloe Priode Tahun 2016-2019 